\title{
PERFORMANCE ANALYSIS AND MODELING OF PASSENGER PUBLIC TRANSPORT SERVICES IN SALATIGA CITY
}

\author{
Mudjiastuti Handajani $^{1}$, Ferry Firmawan ${ }^{1}$, Harmini Harmini ${ }^{2}$
}

${ }^{1}$ Civil Engineering Study Program, University of Semarang, INDONESIA

${ }^{2}$ Electrical Engineering Study Program, University of Semarang, INDONESIA

E-mail: mudjiastuti@usm.ac.id;ferry_firmawan@usm.ac.id;harmini@usm.ac.id

\begin{abstract}
The performance condition of public transportation services in Salatiga City does have an average rating of still good, but it still has classic problems such as there is no passenger stop, public transportation takes a long time to catch up on deposits, and passengers do not know the fare per kilometer that must be paid. These conditions encourage research activities in the form of an analysis of the performance of public transport passengers in Salatiga City (Case Study of the Tamansari - Blotongan Route). The long-term goal of this research is that the resulting analysis can contribute to stakeholders in Salatiga City, especially in terms of (public transport) towards smart transportation. The specific target to be achieved from the research is the analysis and modeling of the performance of passenger public transport services that will be carried out in Salatiga City, in the form of field surveys and secondary data collection, namely: number of vehicles, number of passengers and data in the form of public transport routes: routes, schedules, speeds and Primary forms are: boarding alighting (up and down passengers) and headway (distance between two public transport vehicles). The analytical method used is the analysis and modeling of the performance of passenger public transportation services in accordance with Government Regulation No. 10 of 2012 Directorate General of Land Transportation concerning Minimum Service Standards for Road-Based Mass Transportation. The results showed that the physical condition of the passenger fleet of Salatiga City on the Tamansari - Blotongan PP route was classified as suitable for use. There are a total of 90 fleets that are sufficient for the needs of Salatiga City public transport passengers who want to travel by means of transportation. The results of the performance analysis based on various indicators show that the performance quality of public transportation services in Salatiga City has met the standards set by the Directorate General of Land Transportation. It can be seen from the results of the load factor analysis with a value of 0.72 , the value is included in category A, namely $>0.8$. For the level of satisfaction and level of performance, most of the indicators have met the satisfaction of public transport passengers in Salatiga City, so it is sufficient to maintain it. However, there are indicators of waiting times for public transportation that need to be improved.
\end{abstract}

Keywords: public transportation; performance; modeling; passengers; Salatiga.

\begin{tabular}{cccc}
\hline Received: & Revised: & Accepted: & Available online: \\
$2021-10-25$ & $2021-11-13$ & $2021-12-16$ & $2022-01-08$ \\
\hline
\end{tabular}

\section{INTRODUCTION}

Transportation has become a basic need of society, therefore the continuity of the availability of transportation services in meeting the needs of production, consumption and distribution activities must receive ongoing attention, because the strategic function of transportation is to participate in creating economic stability and continuity of community activities and the movement of the wheels of government. The current highly competitive economic conditions and the everincreasing demands for quality of life have caused people to need a mass transportation that is more feasible, at an affordable rate and has certainty of time to a more appropriate destination. Urban transportation is transportation from one place to another in an urban area bound by a route (Ministerial Regulation, 2019). According to Septian (2015) the behavioral characteristics of passenger public transport on the road can be categorized into three characteristics, namely the travel speed of public passenger cars is low, thereby reducing the speed of other vehicles, passenger car stops are not yet available so they stop at any place, and public passenger cars still violate traffic. cross. 
The Salatiga City Government wants to have a city transportation system, especially passenger public transportation that is environmentally sound, reliable, safe, comfortable, cheap, regular, scheduled and the management of passenger public transportation becomes more modern (Mudjiastuti, 2016). One of the efforts to improve public transportation, especially public transportation for passengers in Salatiga City, is to provide information on the arrival of public transportation in real time so that public transport users can plan when to leave and arrive at the test site (Swati, 2013). Based on this, a monitoring system is needed that is used to monitor transportation movements, in this case the Salatiga City Public Transportation. This system is designed using the Automatic Vehicle Location (AVL) system, with the help of GPS and transmission mechanisms (Mudjiastuti, 2019). Modeling Real Time Passanger Information System for Salatiga City Public Transportation is a tool for public transportation users in Salatiga City so that passengers can find out information on departure schedules, so that passengers can plan a good trip, so that they can change people's behavior from using private vehicles to using public transportation in Salatiga City. So that it will reduce congestion on roads, reduce traffic volume in Salatiga City and reduce consumption of fossil fuels (BBM) made from non-renewable fossils (Mudjiastuti, 2013 and Tejja, 2016).

The formulation of the research problem in this study is how to analyze the performance of public transportation in Salatiga City. The purpose of this study is to determine the performance of public transportation in Salatiga City and then model the performance of public transportation services. The urgency of this research is as a research basis for further research, where the Salatiga City Government in the future wants to make passenger public transportation based on Information Technology (IT).

In the field implementation, the planning of public transportation and traffic needs to be handled thoroughly. Handling public transport traffic requires the concept of land use management including population density in serving public transport routes in rural areas to urban areas (CBD) (Rustiadi E, 2001; Akbardin J, et.al, 2020; Saputro S, Hariyadi ES, 2015).

This public transportation affects environmental conditions so that transportation services are obtained that prioritize safety, punctuality and comfort in driving. In driving, one must determine a basic concept that needs to be considered that public transportation requires a guarantee to serve the general public responsibly. This condition will affect the traffic of public transport both at stops and en route to the destination terminal (Syaiful S, Mudjanarko SW, 2019; Syaiful S, Pratama Y, 2019; Syaiful S, Andana R, 2021; Syaiful S, Irbah AF, 2021; Syaiful S, et.al, 2021; Syaiful S, Syahrulloh F, 2021; Syaiful S, Hariyadi D, 2019).

\section{RESEARCH METHODS}

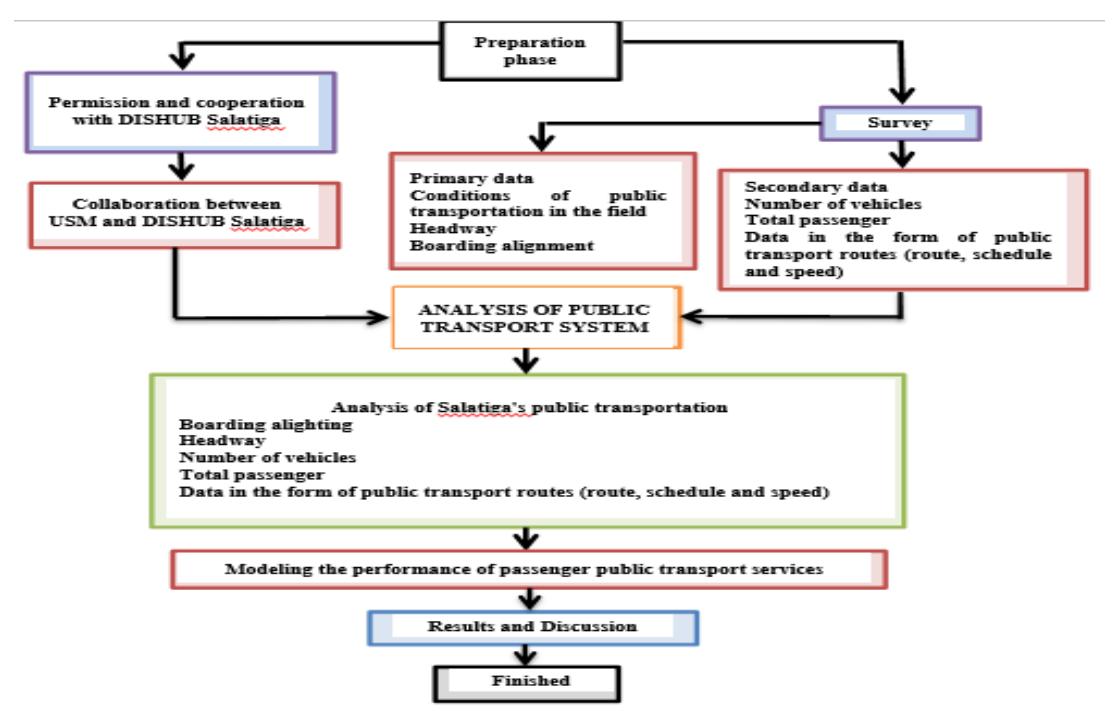

Figure 1. Research Flowchart 
Research activities are planned for a period of 1 year. The preparation stage: includes conducting permits and collaboration with the Salatiga City Transportation Service, field surveys to obtain secondary data, namely: number of vehicles, number of passengers and data in the form of public transportation routes: routes, schedules, speeds and primary form: boarding alighting (up and down passengers) and headway (distance between two public transport vehicles). In addition, data from other relevant agencies. The research flow chart can be seen in Figure 1 above.

This research will be carried out in collaboration with the Salatiga City Government through the Department of Transportation. The analysis on passenger public transportation to be carried out in Salatiga City is in the form of field surveys and secondary data collection, namely: number of vehicles, number of passengers and data in the form of public transportation routes: routes, schedules, speeds and primary forms: boarding alighting (up and down passengers) and headway (distance between two public transport vehicles). The research location is Salatiga City on the public transportation route Tamansari - Blotongan. The research target is the route of public transportation vehicles can be seen in Figure 2.

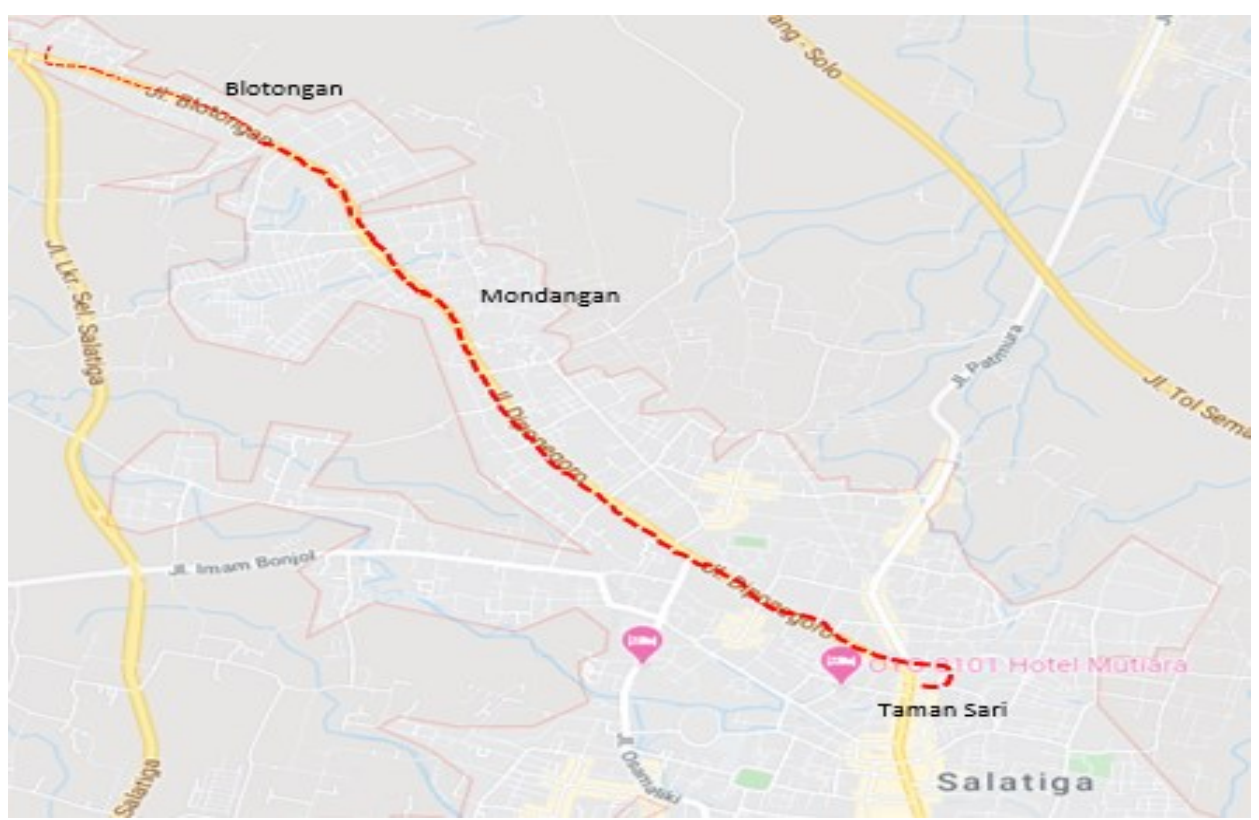

Figure 2. Map of the Tamansari - Blotongan route, Salatiga Source: Personal and google maps

\section{RESULTS AND DISCUSSION}

\section{Overview of Passengers}

\section{Passengers Traveling by Gender}

Based on the data obtained from the questionnaire, passengers who are residents of Salatiga City who travel using public transportation by gender get a percentage value of $60 \%$ of women and $40 \%$ of men. So it can be concluded that the average female passenger of Salatiga City public transport users with a percentage of $60 \%$ can be seen in Table 1 below:

Table 1. Percentage of Respondents

\begin{tabular}{ccc}
\hline Category & Frequency & Percentage \\
\hline Man & 56 & $40 \%$ \\
\hline Woman & 74 & $60 \%$ \\
\hline Total & 130 & $100 \%$
\end{tabular}

Source: Questionnaire Results, 2020 


\section{Passengers Traveling by Age}

Based on the data obtained from the questionnaire results, the age of passengers who travel by public transport passengers in Salatiga City is at most $55 \%$ at the age of $>40$ years, while those aged 25-40 years have a percentage of $25 \%$ and at least $15-25$ years are only has a percentage of 20\%. It can be seen in Figure 3. below:

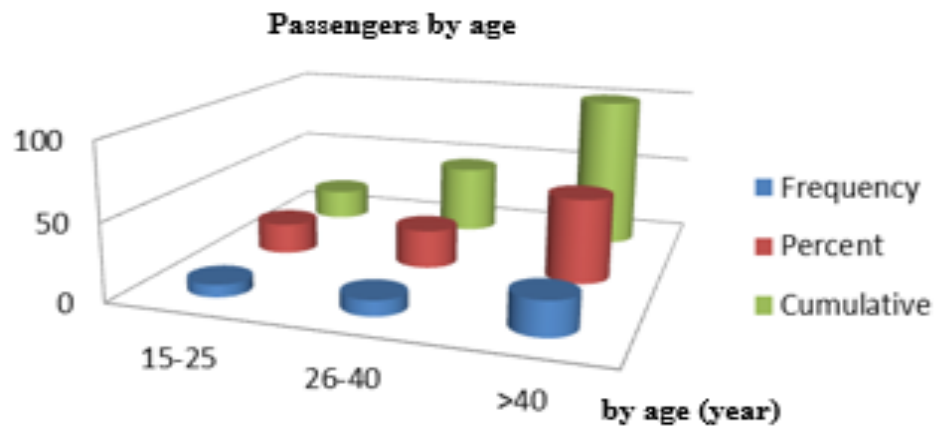

Figure 3. Passengers by Age Source: 2020 Questionnaire Results

\section{Reasons to Use Public Transportation}

The reason people use public passenger cars to carry out daily activities is because there are no other vehicles, easy to get and cheap. From the questionnaire, it was found that the percentage based on low costs was $70 \%$, while for reasons it was easy to get or reach it had a percentage of $22.5 \%$ and the reason there were no other vehicles had a percentage of $7.5 \%$.

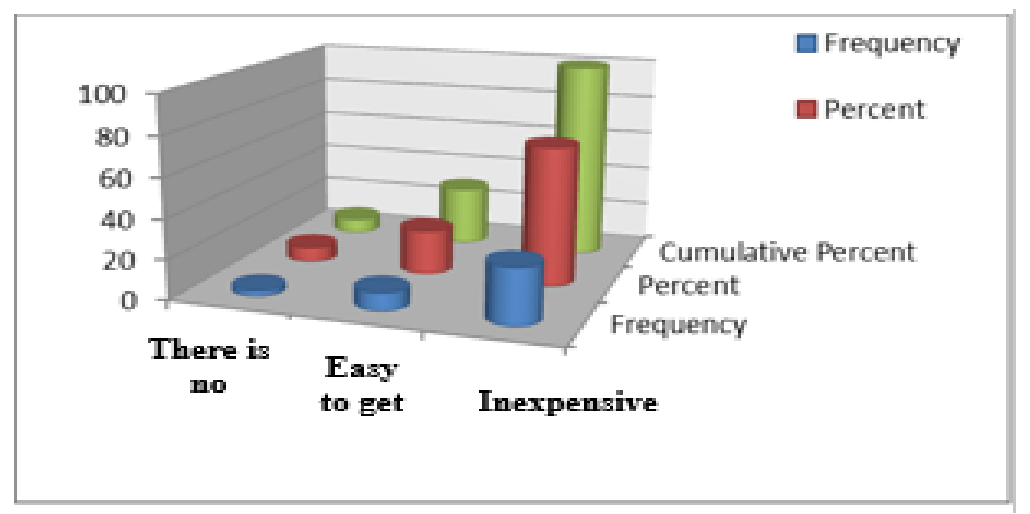

Figure 4. Reasons for Using Public Transportation Source: Questionnaire Results, 2020

\section{Transport Passenger Destination}

The goal is to become one of the factors for the people of Salatiga City in using passenger public transportation to travel from one place to another. In the questionnaire data obtained, $35 \%$ of respondents will use public passenger transportation to travel to the market, while $35 \%$ of respondents will go to school, and for travel with the aim of working $30 \%$ of respondents use passenger public transportation. 


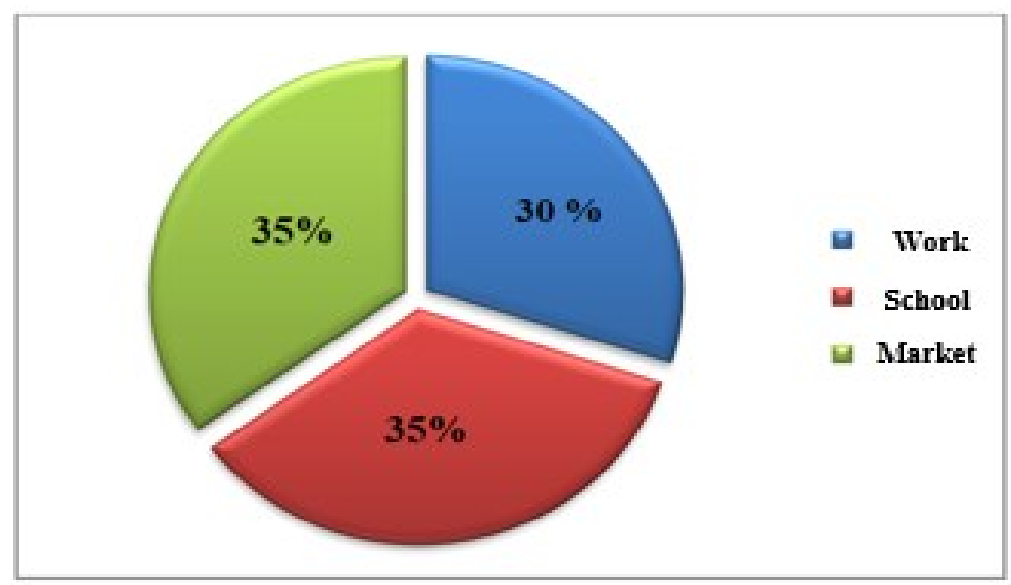

Figure 5. Destination of Transport Passengers Source: Questionnaire Results, 2020

\section{Performance Level and Passenger Satisfaction}

Assessment of the level of performance and the importance of public transportation services in Salatiga City resulted in a calculation between the level of performance and the level of importance.

\section{Satisfaction Level}

The weight of the value on the Likert scale, the value of 3.781 indicates the level of performance in Salatiga City Public Transportation on the reliability dimension is "Quite Good". Based on the results of the answers and the percentage of passengers on public transportation in Salatiga City and then the analysis of the calculations above shows the answer according to the highest level of performance is "Very Satisfied (SP)" and obtains a percentage of $36.83 \%$, respondents who answered satisfied (P) were $25,47 \%$, respondents who answered quite satisfied (CP) of $21.19 \%$, respondents who answered less important (KP) of $11.96 \%$, and respondents who used public transportation and answered not important (TP) obtained a percentage value of $4,55 \%$.

2. Performance Level

The weighted value on the Likert scale, a value of 4.060 indicates the level of performance on public transportation in Salatiga City on the reliability dimension is "Good". Based on the results of the answers and the percentage of Salatiga City public transportation passengers (respondents) and then an analysis of the calculation of the data obtained above shows the answer according to the highest Salatiga City public transportation performance level is "Very Satisfied (SP)" and obtains a percentage of $45.38 \%$, respondents who answered "Satisfied" (P) were $23.50 \%$, respondents who answered "Quite Satisfied" (CP) were $22.83 \%$, respondents who answered "Less Important" (KP) were $8.29 \%$, and respondents who use public transportation in Salatiga City and answer "Not Important" (TP) get a percentage value of $0 \%$.

3. Level of Conformity Between Performance and Satisfaction

The level of conformity is the result of a comparison between the performance score and the passenger interest score which will determine the order of priority for the implementation of the factors that affect the quality of public transportation performance in Salatiga City. The level of conformity between the performance and interests of public transportation passengers in Salatiga City regarding the physical condition and public transportation facilities in Salatiga City has the highest suitability value with a value of $141.395 \%$. From the calculation of the average of each service dimension and the whole, it is obtained as follows:

a. The average level of satisfaction with public transportation services in Salatiga City reached a value of 3,781 so on average it can be said that satisfaction for services for each dimension has reached the Good Enough category.

b. The average level of performance of public transportation services in Salatiga City reached 4.060 , so on average it can be said that the level of passenger satisfaction for services for each dimension has reached the Good category. 
After knowing the average calculation of the performance appraisal and passenger satisfaction, then it can be seen the description of the position of the factors that affect the quality of service contained in the Cartesian diagram "Importance Performance Analysis". The average obtained from the satisfaction level of public transportation services in Salatiga City is 3.781 and the average performance level of public transportation services in Salatiga City is 4.060 which is used as a divisor in the Cartesian diagram with the explanation of the fields in the Cartesian diagram as follows:

1. Quadrant I shows the Main Priority, namely the service performance is below average but the passenger satisfaction value is above average. The service factor in this quadrant must be the main priority faced to create quality services

2. Quadrant II shows Maintain Achievement that the value of service performance and the value of passenger satisfaction is higher than the average value. The service factor in this quadrant maintains its performance because performance and satisfaction have met expectations.

3. Quadrant III shows Low Priority, namely the service value and satisfaction value is low, as well as service performance and passenger satisfaction level are at the same level, which is quite maintained.

4. Quadrant IV shows that the satisfaction value is lower than the average value, and the service value is higher than the average value, indicating that the level of service performance exceeds the level of passenger satisfaction.

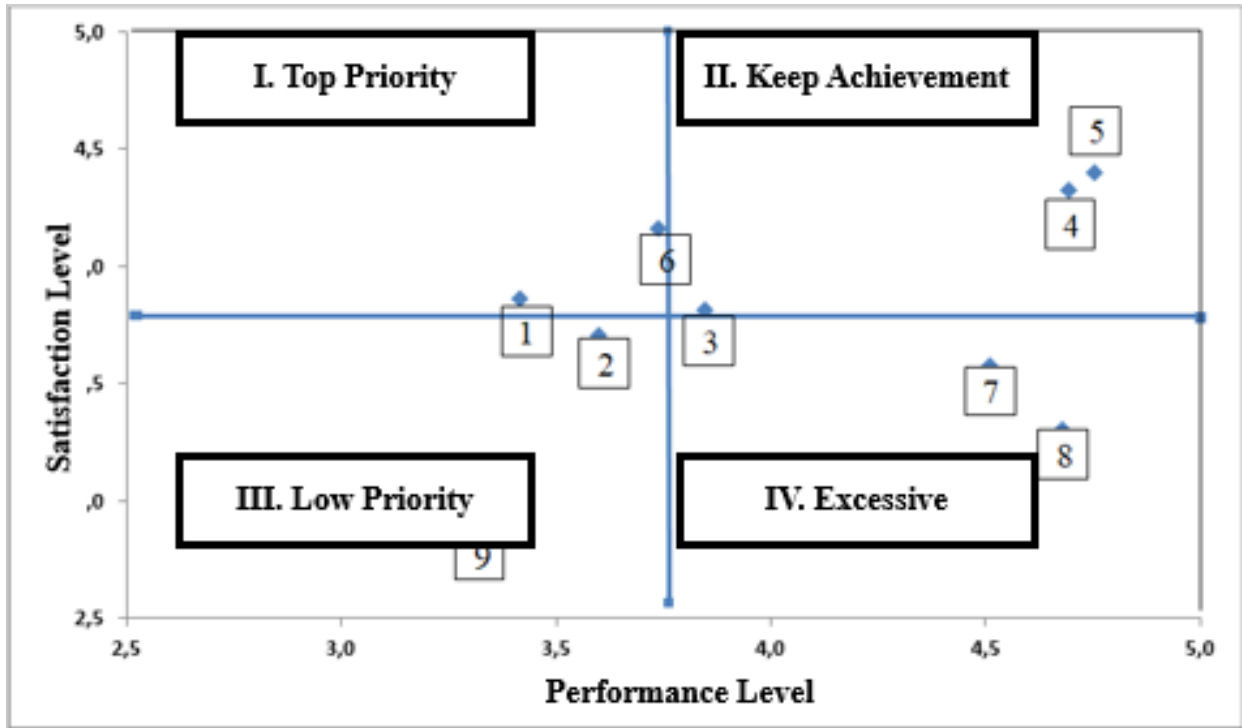

Figure 6. Cartesian diagram Source: Analysis Results, 2021

From Figure 6. there are four quadrants. Quadrant I is an area that contains factors that are considered important by respondents, but in reality they are not as expected (satisfaction is still very low). The attributes included in this quadrant must be improved. Quadrant II is an area that contains factors that are considered important by respondents which are in accordance with what is felt so that the level of satisfaction is relatively higher. Therefore, the attributes included in this quadrant must be maintained. Quadrant III is an area that contains factors that are considered lacking by respondents, but in reality their performance is not too special. Quadrant IV is an area that contains factors that are considered less important and felt too excessive by the respondents. In Figure 4. there are indicators 1-9 as follows:

1. Speed of public transportation in Salatiga

2. Fares for public transportation in Salatiga City

3. Convenience of public transportation in Salatiga

4. Safety of public transportation in Salatiga

5. Safety of public transportation in Salatiga

6. Salatiga City public transportation services 
7. Waiting time between one transportation and the next public transportation

8. Physical condition and public transportation facilities

9. Ease of getting information about public transportation

Based on the results of the questionnaire data processing which is illustrated by the Cartesian diagram "Importance Performance Analysis". Importance Performance Analysis is a method used to rank various elements and sets of services which are then to identify the necessary actions (Kotler, 2013) as follows:

a. Service factors which are the main priority in handling

The service factors that are the main priority in quadrant I of the Cartesian diagram "Importance Performance Analysis" are:

Point 6. Assessment of public transportation services in Salatiga City has a performance level of 3.7 and a satisfaction level of 4.1. Based on the Likert scale, public transportation services in Salatiga City for the level of performance are in the + pretty good category and the level of service is in the important category.

b. Service factors that must be maintained for their performance achievements

Service factors that must be maintained in their performance are service factors that are in quadrant II of the Cartesian diagram "Importance Performance Analysis" namely:

Point 4. Public transportation safety in Salatiga City has a performance level of 4.6 and a satisfaction level of 4.3. Based on the Likert scale, the level of performance and level of satisfaction is in the good category so that it needs to be maintained.

Point 5. The safety of public transportation in Salatiga City has a performance level of 4.7 and a satisfaction level of 4.4. Based on the Likert scale, the level of performance and level of satisfaction is in the good category so that it needs to be maintained.

c. Service factors with low priority in handling

Service factors categorized as low priority are in Quadrant III of the Cartesian diagram "Importance Performance Analysis" namely:

Point 1. The speed of public transportation in Salatiga City has a performance level of 3.4 and a satisfaction level of 3.8. Based on the Likert scale, the level of performance and satisfaction of the speed of public transportation in the City of Salatiga is in the Good Enough category so that it needs to be evaluated and then maintained.

Point 2. Salatiga public transportation fares have a performance level of 3.6 and a satisfaction level of 3.7. Based on the Likert scale, the level of performance and satisfaction of public transport fares in Salatiga City is categorized as Good Enough so that it needs to be evaluated and then maintained.

Point 3. The convenience of public transportation in Salatiga City has a performance level of 3.8 and a satisfaction level of 3.8. Based on the Likert scale, the level of performance and satisfaction of the comfort of public transportation in Salatiga City is categorized as Good Enough so that it needs to be evaluated and then maintained.

Point 9. The ease of getting information about public transportation in Salatiga City has a performance level of 4.7 and a satisfaction level of 4.4. Based on the Likert scale, the level of performance and satisfaction of the ease of getting information about public transportation in the City of Salatiga is in the Good category so it needs to be evaluated and then maintained.

d. Service factor with excessive performance

Service factors categorized as low priority are in Quadrant IV of the Cartesian diagram "Importance Performance Analysis" namely:

Point 7. The waiting time between one transportation and the next public transportation has a performance level value of 4.5 and a satisfaction level of 3.5. Based on the Likert scale, the waiting time for public transportation in Salatiga City for the level of performance is in the good category and the level of service is in the category of quite important. So it is necessary to have the necessary tools to determine the position of public transportation so that Salatiga City public transportation passengers can estimate the arrival time of Salatiga City public transportation. 
Point 8 . The physical condition of Salatiga's public transportation has a performance level of 3.3 and a satisfaction level of 2.8. Based on the Likert scale, the physical condition of Salatiga City's public transportation for the performance level is in the pretty good category and the service level is in the less important category. So the government needs to pay attention to the physical condition of Salatiga's public transportation.

\section{Load Factor}

The load factor table for the Tamansari - Blotongan route on Sunday (Morning) obtained from the survey results, can be seen in Table 2 . below.

Table 2. Load Factor for Tamansari - Blotongan Route Sunday (Morning)

\begin{tabular}{clcccc}
\hline No & Segment & $\begin{array}{c}\text { Ride } \\
\text { (Person) }\end{array}$ & $\begin{array}{c}\text { Down } \\
\text { (Person) }\end{array}$ & $\begin{array}{c}\text { Number of } \\
\text { people }\end{array}$ & $\begin{array}{c}\text { Load } \\
\text { Factor } \\
\mathbf{( \% )}\end{array}$ \\
\hline 1 & Tamansari Terminal & 6 & & 6 & 55 \\
\hline 2 & Kauman & 4 & & 10 & 91 \\
\hline 3 & SMP Pangudi Luhur & 4 & 5 & 9 & 82 \\
\hline 4 & Eks. Terminal Soka & 2 & & 11 & 100 \\
\hline 5 & SalatigaTacticool & & 2 & 9 & 82 \\
\hline 6 & UKSW & 3 & 2 & 10 & 91 \\
\hline 7 & Desa Soka & 1 & 1 & 10 & 91 \\
\hline 8 & Bancan & & 2 & 8 & 73 \\
\hline 9 & Modangan & 2 & & 10 & 91 \\
\hline 10 & SD Blotongan & & 2 & 8 & 73 \\
\hline 11 & Blotongan Pasar Kesongo & & & 0 & 75 \\
\hline & & Average & & & \\
\hline Source & Survey Results, 2020 & & & & \\
\hline
\end{tabular}

Source: Survey Results, 2020

The average load factor condition on trips on Sunday mornings reaches $75 \%$ and the passenger's load factor is full when passing through Ex. Soka Terminal with 11 passengers. Even though the Load Factor on the Blotongan Pasar Kesongo section is the smallest with a percentage of $0 \%$ because it is the last stop as many as 8 people.

Table 3. Load Factor for Tamansari - Blotongan Route Sunday (Afternoon)

\begin{tabular}{llcccc}
\hline No & Segment & $\begin{array}{c}\text { Ride } \\
\text { (Person) }\end{array}$ & $\begin{array}{c}\text { Down } \\
\text { (Person) }\end{array}$ & $\begin{array}{c}\text { Number of } \\
\text { people }\end{array}$ & $\begin{array}{c}\text { Load } \\
\text { Factor } \\
(\%)\end{array}$ \\
\hline 1 & Blotongan Pasar Kesongo & 7 & & 7 & 64 \\
\hline 2 & Jalan baru & 3 & & 10 & 91 \\
\hline 3 & Poltas & 3 & 3 & 10 & 91 \\
\hline 4 & Kemiri & & 1 & 9 & 82 \\
\hline 5 & Unihause & 1 & & 10 & 91 \\
\hline 6 & Pramuka & & 2 & 8 & 73 \\
\hline 7 & Tamansari Terminal & & 8 & 0 & 70 \\
\hline & & Average & & & \\
\hline
\end{tabular}

Source: Survey results, 2020

From Table 3, the Load Factor for the Tamansari-Blotongan route on Sunday afternoon is the most, namely $91 \%$ on the Poltas section with a total of 10 people. While the least is the Tamansari Terminal segment with a $0 \%$ Load Factor due to a decrease in 8 passengers. The average condition of the Tamansari-Blotongan Route Load Factor on Sunday afternoons is $70 \%$ 
Table 4. Load Factor for the Tamansari - Blotongan Route Tuesday (Morning)

\begin{tabular}{clcccc}
\hline No & Segment & $\begin{array}{c}\text { Ride } \\
\text { (Person) }\end{array}$ & $\begin{array}{c}\text { Down } \\
\text { (Person) }\end{array}$ & $\begin{array}{c}\text { Number of } \\
\text { people }\end{array}$ & $\begin{array}{c}\text { Load } \\
\text { Factor } \\
(\%)\end{array}$ \\
\hline 1 & Tamansari Terminal & 7 & & 7 & 64 \\
\hline 2 & Ramayana & 3 & & 10 & 91 \\
\hline 3 & KFC. Salatiga & 1 & & 11 & 100 \\
\hline 4 & Intersection Jl. Wahid Hasim & 2 & 1 & 10 & 91 \\
\hline 5 & Kantor pajak & 2 & 1 & 9 & 91 \\
\hline 6 & Gg. Ki Sono Santiko & 2 & 3 & 8 & 73 \\
\hline 7 & UKSW & 2 & & 8 & 73 \\
\hline 8 & SD Blotongan & 2 & 6 & 55 \\
\hline 9 & Modangan & 6 & 0 & 0 \\
\hline 10 & Blotongan Pasar Kesongo & & & & 72 \\
\hline & & Average &
\end{tabular}

Source: Survey Results, 2020

Viewed from Table 4., the Load Factor condition of public transportation in Salatiga City, the Tamansari Blotongan route, on Tuesday mornings reached an average of $72 \%$ with the most passengers being KFC Salatiga. The average passenger to offices and shopping centers is $28 \%$. The minimum daily load factor is in the Blotongan Pasar Kesongo segment with a percentage of $0 \%$.

Table 5. Load factor for the Tamansari - Blotongan Route Tuesday (Afternoon)

\begin{tabular}{llcccc}
\hline No & Segment & $\begin{array}{c}\text { Ride } \\
\text { (Person) }\end{array}$ & $\begin{array}{c}\text { Down } \\
\text { (Person) }\end{array}$ & $\begin{array}{c}\text { Number of } \\
\text { people }\end{array}$ & $\begin{array}{c}\text { Load } \\
\text { Factor } \\
(\%)\end{array}$ \\
\hline 1 & Blotongan Pasar Kesongo & 7 & & 7 & 64 \\
\hline 2 & Poltas & 3 & 2 & 8 & 73 \\
\hline 3 & Kemiri & 3 & & 11 & 100 \\
\hline 4 & Hotel Surya & 2 & 4 & 9 & 82 \\
\hline 5 & UKSW & 1 & & 10 & 91 \\
\hline 6 & Tamansari (Jl. Pemuda) & & 1 & 9 & 82 \\
\hline 7 & Tamansari Terminal & & & 0 & 0 \\
\hline & & & & \\
\hline
\end{tabular}

Source: Survey Results, 2020

On Tuesday afternoon the Tamansari $\neg \neg-$ Blotongan route has an average load factor of $70 \%$. It can be seen in table 5. The condition of the load factor is the least when it is on the Tamansari terminal segment, while when passing through the road in the Kemiri area, public passenger cars have a load factor of $100 \%$ (full of passengers).

From the survey results, it can be seen the comparison of the filling level with the seating capacity of a public transportation mode. The daily average load factor is

load factor $\quad=($ Number of Passengers in MPU)/(Number of seats in MPU) X $100 \%$

load factor

$$
=8 / 11 \times 100 \%
$$$$
=72 \%
$$

Based on the Directorate General of Land Transportation in 2009 the average daily load factor is in category $\mathrm{A}$, which is $<0.8$.

In this study it can be concluded that the public's attraction to public passenger cars is increasing every year. Although not as much as expected, at least the community is enthusiastic about public transportation car services. Value of load factor, headway and speed. It can be seen in Figure 7 below. 


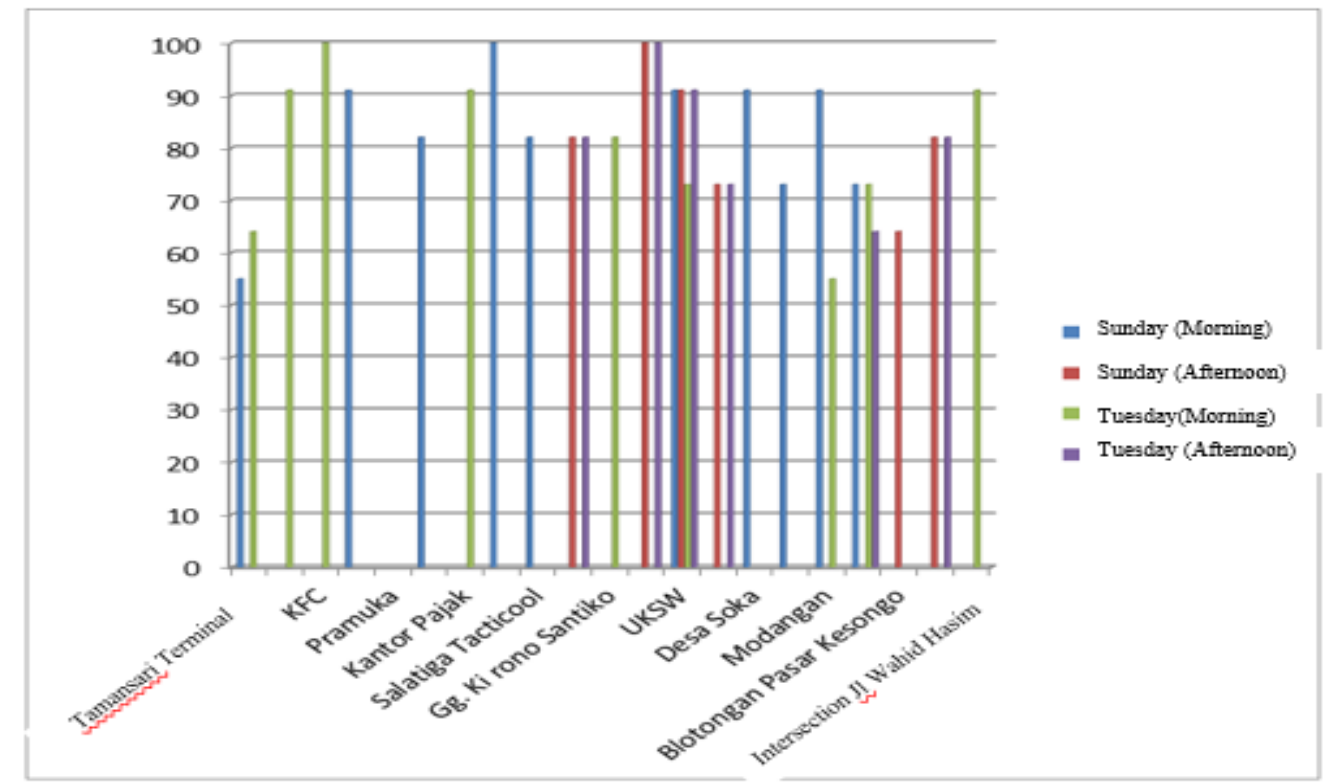

Figure 7. Value of Load Factor, Headway, and Speed Source: Analysis Results, 2020

\section{Economical Overview}

Calculating the certainty of saving travel time using the Real Time Passenger Information System model:

The certainty of travel time for moving private vehicles using Salatiga City Public Transportation with the existence of a Passanger Information System for passengers who can provide information to passengers about the existence of Salatiga City public transportation locations. The existing facilities in the Passanger Information System are expected to help users (passengers) obtain route information taken by Salatiga City Public Transport. Information on distance and travel time at each stop traversed by public transportation can be useful information for users or passengers when using public transportation services for passengers who are currently operating. The certainty of travel time can minimize the waiting time of passengers on public transportation in Salatiga City at each destination, so that passengers can predict and use it.

\section{Time more efficiently and effectively.}

For example: In order not to be late for school, students who will depart do not wait for the arrival of public transportation that is too long.

\section{Mode Choice Approach}

This method tries to determine the time value of the model to estimate the ratio of the selection of the transportation method used. In this method, the comparison of options is assumed which is a function of 2 variables, namely operational costs and time costs. Time value is defined as the ratio between travel time factor and travel cost factor.

Choice ratio $(\mathrm{Pi})$

$$
=a_{-} 0+a_{-} 1+\left(C_{-} i-C_{-} j\right)+a_{-} 2\left(T_{-} i-T_{-} j\right)
$$

Information :

$$
\begin{array}{ll}
\mathrm{Pi} & =\text { Choice ratio of the first mode, } \\
\mathrm{i}, \mathrm{j} & =\text { Alternative mode, } \\
\mathrm{C}, \mathrm{T} & =\text { Cost }(\mathrm{C}) \text { and Time }(\mathrm{T}), \\
\text { a_0,a_1,a_2 } & =\text { Coefficient. }
\end{array}
$$




\section{Income Approach}

The time value by considering per capita income (GRDP) can be formulated as follows:

Time Value

$=(\mathrm{GRDP} / \mathrm{JP}) / \mathrm{WKT}$

Information :

GRDP

JP

WKT

\section{Fuel Usage}

If there is a real-time passenger information system, it will shorten the waiting time for passengers and public transportation in Salatiga City can replace private vehicles to meet people's travels, so a large number of vehicles can be 'caged' for a certain period of time, such as during Monday to Friday. If each private car consumes an average of 10 liters of fuel per day, then 1,000 cars can save IDR 10,000L/day.

\section{Environmental Overview}

Salatiga City is a city with a total population of 194,084 people. Therefore, a good urban transportation is to use public transportation. The city government is obliged to provide good public transportation for the community. Public transportation in Salatiga City can usually accommodate 8 passengers, but due to the Covid-19 pandemic, public transportation can only accommodate 5 passengers. By using public transportation, it can save fuel consumption (BBM). In the end, the city transportation system will get better and Smart Transportation achievements can be realized towards an environmentally friendly Smart City (Sustainable Transportation) for cities in Indonesia, especially Salatiga City.

Architecture and Modeling of Real Time Passanger Information System of Salatiga City Public Transport

Passenger Information System is a method to provide information to passengers about the status of certain modern and real-time transportation modes. This system was created to assist passengers in finding information, saving time and increasing passenger comfort. (Suakanto et.al. 2017)

According to Matsumoto et.al (2016), the current Passenger Information System consists of an information screen that uses an LED screen to display information in indoor or outdoor applications. This system is in the form of drivers for monitoring and integration of each device. The GPS module is used to determine the actual location of passenger public transport, to publish announcements and broadcasters for public transport stops, and to provide wireless communication with a central network system. The main part of the Salatiga City passenger public transport information system is a simulator application, public transport simulator and processing server. The architecture and modeling of the system can be explained as follows:

\section{Simulator app}

The application uses a web- and android-based application, which includes displays on passenger public transport bookings, mobile applications and control room applications. The service will always require updating of new information to the central server.

\section{Public transport simulator}

Its main function is to download the name or code of public transport and the coordinates of the stopping point of passenger public transport, calculate the distance and direction of public transport, and send information to the server using the GPRS network. The information sent includes passenger IDs identified through the RFID (Radio Frequency Identification Device) network, so that every passenger boarding public transportation must tap the ID when getting on and off the transportation. The fare of public transport passengers will be known based on the ID card. The GPS receiver will calculate the location of public transportation in real time which will 
be stored on a simulator located on public transportation, as well as the location of longitude and latitude on public transportation will be sent to the central server in stages using the GPRS network. Units in public transportation will download the name or code of public transportation of passengers and the coordinates of the public transportation points on the server. Analysis and calculation of public transport time contains an algorithm that will calculate the arrival time of public transport through the route traversed.

\section{Processing server}

This server is located at the center of the information system, with the following functions:

Maintain a database of all routes, public transportation that serves all routes, places to find public transportation.

Receive the location and speed of the public transport vehicle unit.

Calculate the estimated arrival time of public transport with one another according to the place where the public transport is located.

\section{Reply to requests from android users based on queries sent by the android system.}

Host an internet web page that allows administrators to track public transport in real time and get time estimates between public transport and public transport.

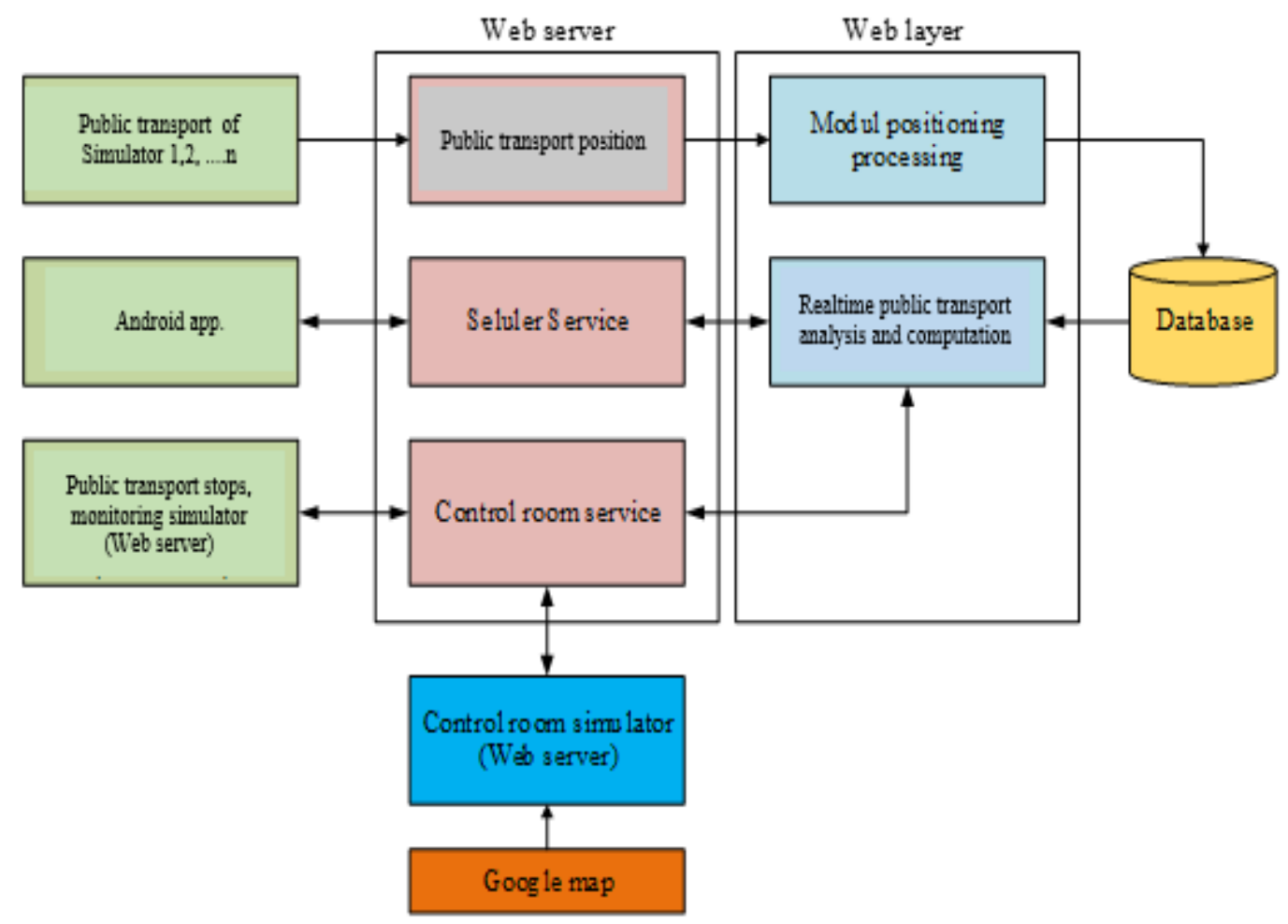

Figure 8. Architecture and model of Real Time Passenger Information System of Salatiga City Public Transport 


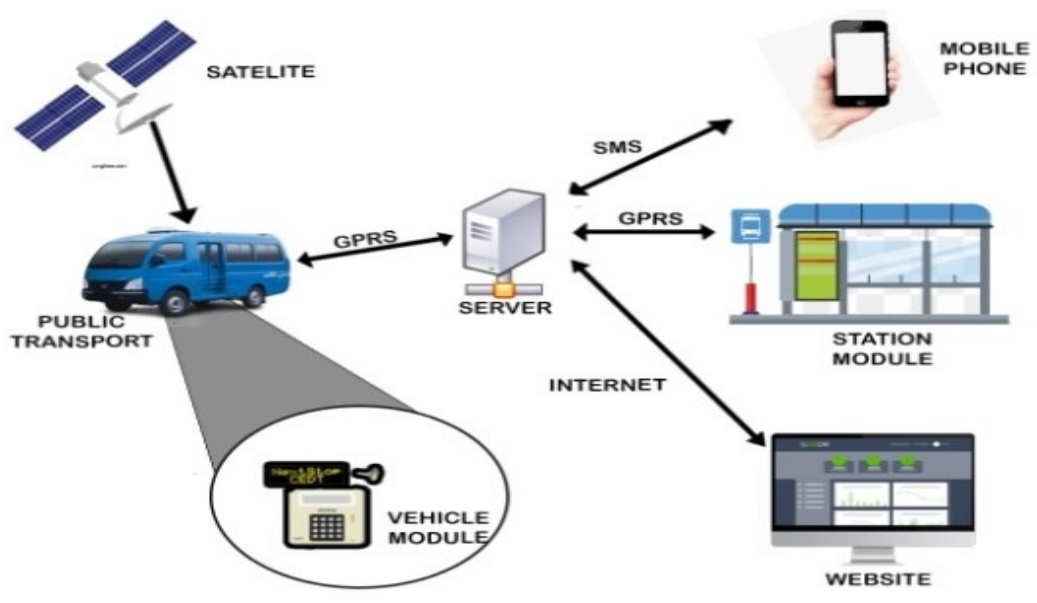

Figure 9. Diagram of Salatiga City's public transportation information system

Figure 9. describes how the public transportation information system will be applied to public transportation in Salatiga City. This system uses satellite communication and GPRS. Satellite communication based on googlemaps which will be used to detect the position of the movement of public transport locations, then the position data of public transport is stored on the database server via GPRS communication. Existing data will be stored in position logging. Passenger public transport will be equipped with a module that can receive and send signals to a server called the vehicle module. The data on the server will be processed and displayed on the website via the internet and can also be accessed by users via Android or also via SMS to users. At public transport stops or public transport stops (ngetem) a monitoring display will be installed to display the movement of public transport. RFID will also be applied to this system to detect every passenger who rides public transportation so that the number of passengers can be estimated. This serves to limit the number of passengers in one public vehicle. With the Covid-19 pandemic, there are many restrictions that must be implemented, including users of public transportation. Each public transportation will be limited to 5 passengers, if the vehicle capacity is full, the system will send a signal to the display stop or to the user with a notification that the vehicle is full and asked to take the next public transportation.

\section{CONCLUSION}

Based on the results of data analysis and data calculations as well as observations made during data collection, it can be concluded that the physical condition of the passenger fleet of Salatiga City on the Tamansari - Blotongan PP route is classified as suitable for use. There are 90 fleets that are sufficient for the needs of Salatiga City public transport passengers who want to travel by means of transportation, and based on a performance analysis based on various indicators, it shows that the performance quality of Salatiga City public transportation services has met the standards set by the Directorate General of Land Transportation. However, there are indicators of waiting times for public transportation that need to be improved. From these indicators, a model of the Passanger Information System tool will be made, so that it can provide information to passengers about the existence of the Salatiga City public transportation location regarding the certainty of travel time for moving private vehicles using Salatiga City Public Transportation. The existing facilities in the Passanger Information System are expected to help users obtain route information taken by the Salatiga City Public Transport.

\section{REFERENCES}

Direktorat Jendral Perhubungan Darat (2009. Tentang Lalu Lintas dan Angkutan Jalan beserta Peraturan Pelaksanaannya. Departemen Perhubungan. Jakarta. (Indnesian).

Ernan Rustiadi. 2001. Alih Fungsi Lahan dalam Perspektif Lingkungan Perdesaan, Transmigrasi dan Pengembangan Wilayah, Disampaikan pada Lokakarya Penyusunan Kebijakan dan Strategi 
Pengelolaan Lingkungan Kawasan Perdesaan di Cibogo Bogor, tanggal 10-11 Mei 2001. (Indonesian).

Juang Akbardin, Danang Parikesit, Bambang Riyanto, Agus Taufik Mulyono and Syaiful Syaiful. 2020. Modeling of trips assignment analysis for roads network system based on transportation needs of export commodity. ARPN Journal of Engineering and Applied Science. 15(21): 24632470. http://www.arpnjournals.org/jeas/research_papers/rp_2020/jeas_1120 8379.pdf

Kotler, Philip., Keller, Kevin L. 2013. Manajemen Pemasaran, Jilid Kedua, Jakarta: Erlangga

Matsumoto, K., Nakada, K., \& Azuma, K. (2014). Development of On-board Passenger Information Display. Hitachi Vol. 63 No. 10.

Mudjiastuti Handajani. (2013) The Urban Transportation System and Fuel Consumtion of Metropolitan and large City. The 13th International Conference On QiR (Quality in Research).

Mudjiastuti Handajani. (2016). Pengukuhan Guru Besar Teknik Sipil. Fakultas Teknik Universitas Semarang. Solusi Hemat Bahan Bakar Minyak (BBM) Menuju Transportasi Berkelanjutan. (Indnesian).

Mudjiastuti Handajani. (2019). The Efficiency of a Bus Rapid Transit Utilizing a Passenger Information System. 2nd International Symposium on Transportation Studies in Daveloping Countries (ISTSDC) Vol 193

Peraturan Menteri Perhubungan Republik Indonesia. (2019). Penyelenggaraan Angkutan Orang Dengan Kendaraan Bermotor Umum Dalam Trayek No. 15 Peraturan Menteri Perhubungan Republik Indonesia. (Indnesian).

Saputro S dan Eri Susanto Hariyadi. 2015. Evaluasi Fungsional dan Struktural Perkerasan Lentur pada Jalan Nasional Bandung-Purwakarta dengan Metode AUSTROADS 2011, Jurnal HPJI Vol. 1 No. 2 Juli 2015, hal: 85-92. (Indonesian).

Septian Adhi Pratomo. (2015). Kajian Karakteristik Perilaku Angkutan Umum Penumpang Dan Pengaruhnya Terhadap Kinerja Lalu Lintas. Scaffolding Vol. 4 No.1. (Indnesian).

Sukanto,Sinung, Herry Sitepu, dkk. Perancangan dan Implementasi Sistem Informasi Penumpang. 2017. Prosiding SNFA (Seminar Nasional Fisika dan Aplikasinya). E-ISSN: 2548-8325 / P-ISSN 2548-8317. (Indnesian).

Swati, Chandurkar, 2013, Implementation of Real Time Bus Monitoring and Passenger Information System, International Journal of Scientific and Research Publication, Volume 3, Issue 5, May 2013, ISSN 2250-3153.

Syaiful Syaiful, Sri Wiwoho Mudjanarko. 2019. Noise of Motor Vehicles at from of Baiturrahman Great Mosque Semarang City, The Spirit Of Society Journal, 2 (2) March 2019. https://jurnal.narotama.ac.id/index.php/scj/article/view/902

Syaiful Syaiful, Yogi Pratama. 2019, Sustainable Studies about General Public Transport Performance in the City of Bogor. ARPN Journal of Engineering and Applied Science. 14(18): 3241-3247.http://www.arpnjournals.org/jeas/research_papers/rp_2019/jeas_0919_7925.pdf

Syaiful Syaiful, Rendy Andana. 2021. PASSENGER CAR SPEED ASSESSMENT RELATIONSHIP TO THE NOISE CAUSED, ASTONJADRO: CEAESJ 10(1):41-49. http://ejournal.uika-bogor.ac.id/index.php/ASTONJADRO/article/view/3494

Syaiful Syaiful, Almas Fathin Irbah, 2021. STUDY OF NOISE ON PASSENGER CAR SPEED, ASTONJADRO: CEAESJ 10(2):195-203. http://ejournal.uikabogor.ac.id/index.php/ASTONJADRO/article/view/3571

Syaiful Syaiful, Hermanto Siregar, Ernan Rustiadi, Eri Susanto Hariyadi, 2021. ANALYSIS OF MOTORCYCLE TRAFFIC SPEED WHICH CREATES NOISE IN FRONT OF WIYATA MANDALA JUNIOR HIGH SCHOOL DURING THE COVID-19 PANDEMIC. 
ASTONJADRO: CEAESJ 10(2):225-236. http://ejournal.uikabogor.ac.id/index.php/ASTONJADRO/article/view/4772

Syaiful Syaiful, Fery Syahrulloh, 2021. Geometric planning of Toll Roads on Ringroad road development. ARPN Journal of Engineering and Applied Sciences 16 (18), 1900-1914. http://www.arpnjournals.org/jeas/research_papers/rp_2021/jeas_0921_8693.pdf

Syaiful Syaiful, Doni Hariyadi, 2019. CASE STUDY ON SUSTAINABLE T-JUNGTION CIBINONG CITY MALL (CCM) IN BOGOR INDONESIA. ARPN Journal of Engineering and Applied Sciences 14 (17), 2960-2971

Tejja Bramantya. 2016. Konsumsi Bahan Bakar Pertamina Diklaim Melonjak Jelang Lebaran. Mobil Outomotif Net.com. (Indnesian). 